\title{
The Relationship Between Democratic Parenting Patterns and Self- Efficacy in Class XI Social Studies Students at SMA N 1 Ranah Batahan
}

\author{
Hubungan Antara Pola Asuh Demokratis dengan Efikasi Diri pada Siswa Kelas \\ XI IPS di SMA N 1 Ranah Batahan
}

\author{
Firdaus \\ Universitas Nahdlatul Ulama Sumatera Barat \\ daussumbar@yahoo.com
}

\begin{abstract}
The purpose of this study is to explain the category of democratic fostering patterns, the category of self-efficacy, and the relationship between democratic parenting patterns and the self-efficacy of students of grade XI IPS at SMA N 1 Ranah Batahan West Pasaman Regency. The research method used is quantitative research method with correlation technique. The population in this study was grade XI students of IPS SMA N 1 Ranah Batahan West Pasaman Regency numbered 119 students with a research sample of 92 students. Withdrawal of research samples using proportional random sampling. The data collection technique in this study is psychological scale, which is guided by the scale of the modified Likert model. The analyst technique used is pearson correlation. The results showed that $85.9 \%$ of students had a high democratic parenting pattern and as many as $58.7 \%$ of students showed low self-efficacy. The correlation results showed a relationship between democratic parenting patterns and self-efficacy. Effective contribution of democratic fostering pattern to self-efficacy of $22.3 \%$.
\end{abstract}

Keywords: democratic parenting patterns, self-efficacy

Abstrak

Tujuan dari penelitian ini adalah untuk menjelaskan kategori pola asuh demokratis, kategori efikasi diri, dan hubungan antara pola asuh demokratis dengan efikasi diri siswa kelas XI IPS di SMA N 1 Ranah Batahan Kabupaten Pasaman Barat. Metode penelitian yang digunakan adalah metode penelitian kuantitatif dengan teknik korelasi. Populasi dalam penelitian ini adalah siswa kelas XI IPS SMA N 1 Ranah Batahan Kabupaten Pasaman Barat berjumlah 119 siswa dengan sampel penelitian berjumlah 92 siswa. Penarikan sampel penelitian dengan menggunakan proporsional random sampling. Teknik pengumpulan data dalam penelitian ini adalah skala psikologi, yang berpedoman pada skala model Likert yang dimodifikasi. Teknik analisi yang digunakan adalah pearson correlation. Hasil penelitian menunjukkan bahwa $85,9 \%$ siswa memiliki pola asuh demokratis yang tinggi dan sebanyak 58,7\% siswa menunjukkan efikasi diri yang rendah. Hasil korelasi menunjukkan adanya hubungan antara pola asuh demokratis dengan efikasi diri. Sumbangan efektif pola asuh demokratis terhadap efikasi diri sebesar $22,3 \%$.

Kata kunci: pola asuh demokratis, efikasi diri

\section{PENDAHULUAN}

Pada masa awal usia sekolah, pada umumnya anak dituntut untuk dapat mengerjakan atau menyelesaikan sesuatu dengan baik bahkan sempurna. Kemampuan melakukan hal-hal tesebut menumbuhkan efikasi diri dan kepercayaan diri atas kecakapan atau kemampuan diri hingga pada akhirnya akan memiliki penilain yang positif terhadap diri sendiri. Kalau tidak, pada diri anak akan mulai tumbuh bibit perasaan rendah diri (inferiority) yang mungkin akan dibawanya pada taraf perkembangan psikososial selanjutnya (Hardjasuganda Djukanda, 2008:5). Orang tua merupakan area terdekat pada anak. Seorang anak sangat membutuhkan kasih sayang, perlindungan, rasa aman, sikap dan perlakuan yang adil dari orang tua. Bagaimana pengasuhan orang tua yang diberikan pada anak, apakah permisif atau serba boleh, otoriter yang tidak membolehkan anak berbuat apapun, ataukah bersifat demokratis yang merupakan perpaduan dari 


\section{Firdaus}

Universitas Nahdlatul Ulama Sumatera Barat

keduanya. Setiap gaya pengasuhan orang tua ini sangat dipengaruhi oleh kualitas interaksi antara anak dengan orang tuanya yang semuanya akan memberikan dampak yang berbeda pada anak, bagaimana anak akan terbentuk tentunya didapat dari pembiasaan-pembiasaan yang terjadi pada situasi rumah. Hal inilah yang terkadang mendasari anak untuk mengembangkan dirinya (Rita Eka I.,dkk, 2008:15).

Lingkungan yang paling berpengaruh dalam kehidupan anak adalah orang tua. Peran orang tua sangat diperlukan anak dalam tumbuh kembangnya. Ketika remaja menghadapi krisis akademik, remaja mengharapkan dorongan yang berasal dari keluarga terutama rang tuanya (Hurlock, 1980:86). Kondisi dimana sekarang banyak orang tua disibukkan dengan pekerjaan diluar rumah menyebabkan interaksi antara orang tua dengan anak berkurang atau terbatas. Pada dasarnya, perkembangan diri anak dalam hal efikasi diri berawal dari keluarga yang sangat dipengaruhi oleh pola asuh yang diterapkan oleh kedua orang tua.

Ada dua dimensi yang mendasari perilaku orang tua dalam mengasuh anak yaitu responsiveness dan demandingness. Parental responsiveness menunjukkan tingkat orang tua dalam menanggapi kebutuhan anak seperti menerima anak apa adanya dan mendukung anak. Parental demandingness menunjukkan sejauh mana harapan dan orang tua agar anak berperilaku dewasa dan bertanggung jawab. Kedua aspek pola asuh parental responsiveness dan parental demadingness bersifat independen antara satu dengan yang lain, sehingga memungkinkan adanya orang tua yang sangat demanding tanpa adanya responsive.

Pendekatan tipologi memahami bahwa terdapat dua dimensi dalam pelaksanaan tugas pengasuhan, yaitu demandingness dan responsiveness. Demandingness merupakan dimensi yang berkaitan dengan tuntutan-tuntutan orangtua mengenai keinginan menjadikan anak sebagai bagian dari keluarga, harapan tentang perilaku dewasa, disiplin, penyediaan supervisi, dan upaya menghadapi masalah perilaku. Faktor ini mewujud dalam tindakan kontrol dan regulasi yang dilakukan oleh orangtua. Responsiveness merupakan dimensi yang berkaitan dengan ketanggapan orangtua dalam hal membimbing kepribadian anak, membentuk ketegasan sikap, pengaturan diri, dan pemenuhan kebutuhan-kebutuhan khusus. Faktor ini mewujud dalam tindakan penerimaan, suportif, sensitif terhadap kebutuhan, pemberian afeksi dan penghargaan (Lestari, 2012:48).

Orang tua yang memiliki responsiveness dan demanding seimbang adalah orang tua dengan tipe authoritative. Anak dengan pola asuh authoritative akan belajar untuk bertindak tanpa dipenuhi rasa takut atau mempunyai keyakinan akan diri yang tinggi akan konsekuensi yang akan dialami dan mereka dapat berinteraksi sosial yang baik.

Kemampuan remaja dalam menyelesaikan tugas-tugas akademik yang dihadapi tidak hanya dipengaruhi potensi kognitif yang dimiliki oleh remaja seperti inteligensi, akan tetapi juga sangat dipengaruhi oleh keyakinan remaja mengenai kemampuan dirinya dalam menyelesaikan tugas-tugasnya. Karakteristik alam penyesuaian diri yang ada pada remaja dapat dilihat dari penyesuaian diri mereka pada peran dalam pendidikan, norma sosial dan penyesuaian diri terhadap kecemasan, konflik dan frustasi (Ali \& Anshori, 2011:112). Masa remaja bersekolah adalah masa-masa dimana remaja malas untuk melakukan kegiatan belajar disekolah. Ada beberapa faktor yang membuat anak menjadi malas untuk bersekolah seperti: beban yang diberikan oleh sekolah terlalu banyak dan berat membuat remaja merasa tidak yakin akan kemampuan yang dimilikinya, sistem belajar yang ada disekolah tidak menarik, remaja tidak menyukai pelajaran yang diberikan, orang tua tidak memberikan panutan dan tidak memberikan nasehat yang tepat pada anak. Hal-hal tersebut dapat membuat remaja tidak yakin tentang kemampuan dirinya dalam menyelesaikan tugas-tugas disekolah atau tidak memaksimalkan peran mereka dalam bersekolah.

Persaingan yang pesat pada saat ini yang terjadi di dunia pendidikan, yang pada akhirnya akan membawa pengaruh ke dunia karir kedepannya, maka sedini mungkin orang tua harus

DOI UNTUK ARTIKEL INI

https://doi.org/10.37010/int.v2i2.483
Scan barcode untuk mengunjungi OJS

kami 
mampu menanamkan efikasi diri kepada anak-anaknya. Semakin tinggi efikasi diri yang dimiliki oleh remaja, maka remaja akan mudah menetapkan tindakan apa yang harus dilakukannya. Efikasi diri juga sebagai mediator yang mempunyai pengaruh yang cukup besar kepada remaja untuk menentukan dalam memilih minat yang diinginkan, baik dalam bidang akademis maupun yang bukan bidang akademis. Bila remaja mampu untuk menyelesaikan tugas-tugas dalam hal memutuskan untuk memilih sesuatu, maka biasanya remaja akan mampu memutuskan dengan segera. Remaja yang mempunyai efikasi diri yang tinggi, maka akan berusaha dengan keras untuk menyelesaikan kesulitan yang dihadapi dan berusaha untuk bertahan dalam menyelesaikan suatu tugas, namun sebaliknya remaja yang efikasi diri yang rendah, ketika mendapatkan tugas dan merasa mengalami sesuatu kesulitan, maka ia mudah merasa terganggu dan akan dengan mudah menyerah untuk menyelesaikan tugas yang diberikan kepadanya. Karakteristik individu yang memiliki efikasi diri yang tinggi adalah ketika individu tersebut merasa yakin mampu menangani secara efektif peristiwa dan situasi yang dihadapi, tekun dalam menyelesaikan tugastugas, percaya pada kemampuan diri yang dimiliki, memandang kesulitan sebagai tantangan bukan ancaman dan suka mencari situasi baru, menetapkan sendiri tujuan yang menentang dan meningkatkan komitmen yang kuat terhadap dirinya, menanamkan usaha yang kuat dalam apa yang dilakukan dan meningkatkan usaha saat menghadapi kegagalan, berfokus pada tugas dan memikirkan strategi dalam menghadapi kesulitan, cepat memulihkan rasa mampu setelah mengalami kegagalan, dan menghadapi stres atau ancaman dengan keyakinan bahwa mampu mengontrolnya.

Salah satu pola asuh yang dikenal dalam pola asuh adalah pola asuh demokratis dimana pola asuh ini ditandai dengan sikap orangtua yang menerima, responsif, dan sangat memperhatikan kebutuhan anak yang disertai dengan tuntutan, kontrol, dan pembatasan. Pola asuh demokratis disebut juga pengasuhan otoritatif merupakan pola asuh yang mendorong anakanak agar mandiri tetapi masih menetapkan batasan-batasan dan pengendalian atas tindakantindakan mereka.

Menurut Dariyo (dalam Fuadi, 2012) pola asuh demokratis akan berjalan efektif bila ada tiga syarat yaitu:

a. Orangtua dapat menjalankan fungsi sebagai orangtua dengan memberi kesempatan kepada anak untuk mengemukakan pendapatnya.

b. Anak memiliki sikap dewasa yakni dapat memahami dan menghargai orangtua sebagai tokoh utama yang memimpin keluarganya.

c. Orangtua belajar memberi kepercayaan dan tanggung jawab tehadap anaknya.

Pola asuh demokratis adalah pola asuh yang ditandai dengan pengakuan orang tua terhadap anak-anaknya. Kemudian anak diberi kesempatan untuk tidak tergantung kepada orang tua. Orang tua sangat memperhatikan kebutuhan anak dan mencukupinya dengan pertimbangan factor kepentingan dan kebutuhan. Pola asuh ini orang tua memberikan sedikit kebebasan keada anak untuk memilih apa yang dikehendaki dan apa yang diinginkan terbaik untuk dirinya, anak diperhatikan dan didengakan saat anak berbicara dan memberikan kesempatan kepada anak untuk memberikan pendapatnya.

Pola asuh ini memiliki dampak yang baik untuk kepribadian anak, anak menjadi mandiri, kontrol diri yang baik, percaya diri dan dapat berinteraksi dengan baik, dan lain-lain. Orangtua yang memiliki karakteristik sikap demokrasi memperlakukan anak sesuai dengan tahapan perkembangan usia anak dan memerhatikan serta mempertimbangkan keinginankeinginan anak. Anak dengan pola pengasuhan orang yang demokratis akan menunjukkan sikap atau perilaku tanggung jawab yang besar, dapat menerima perintah dan dapat diperintah sesuai dengan wajar, dapat menerima kritik secara terbuka, memiliki keberanian untuk berinisiatif dan kreatif, memiliki emosi yang stabil, dapat menghargai pekerjaan atau jerih payah orang lain, mudah beradaptasi, lebih toleran, mau menerima dan memberi. Memiliki rasa sosial yang besar,

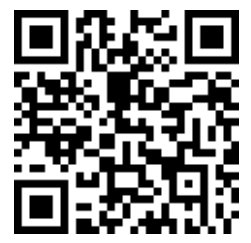

DOI PUBLIKASI https://doi.org/10.37010/int.v2i2 


\section{Firdaus}

Universitas Nahdllatul Ulama Sumatera Barat

konsep dirinya yang positif, dapat bekerja sama dan kontrol diri yang besar (Diana Mutiah, 2010:89).

Menurut Baumrind (dalam Fuadi 2012) pola asuh demokratis memiliki aspek-aspek sebagai berikut:

1. Kasih sayang

2. Komunikasi

3. Kontrol

4. Tuntutan kedewasaan

Sejalan dengan pendapat tersebut, Waruan (dalam Fuadi 2012) yang mengemukakan beberapa aspek dalam pola asuh demokratis orangtua, yaitu:

1. Kasih sayang

Penuh kehangatan, cinta, perawatan dan perasaan kasih serta keterlibatan yang meliputi penghargaan dan pujian terhadap prestasi anak.

2. Komunikasi anak dengan orangtua

Terjalinnya komunikasi yang baik antara anak dengan orangtua, yaitu orangtua selalu menanyakan bagaimana pendapat dan perasaan anak bila mempunyai persoalan yang harus dipecahkan.

3. Kontrol

Merupakan usaha mempengaruhi aktivitas anak secara seimbang untuk mencapai tujuan, sehingga tidak menimbulkan ketergantungan pada anak, menjadikan anak bertanggung jawab serta ditaatinya aturan orangtua dengan penuh kesadaran.

4. Tuntutan kedewasaan

Merupakan kegiatan memberi pengertian kepada anak untuk mencapai suatu tingkat kemampuan baiksecara intelektual, sosial dan emosional dengan selalu memberikan kesempatan kepada anak untuk berdiskusi dengan orangtuanya (Fuadi, 2012: 4)

Menurut Mussen 1994 (dalam Fuadi, 2012) mengemukakan beberapa faktor yang dapat mempengaruhi pola asuh demokratis orangtua yaitu:

1. Faktor nilai yang dianut orangtua

2. Faktor kepribadian

3. Tingkat pendidikan orangtua

4. Faktor sosial ekonomi

Di samping itu menurut Hurlock (dalam Fuadi, 2012) faktor yang dapat mempengaruhi pola asuh demokratis orangtua adalah:

1. Faktor nilai yang dianut orangtua yaitu nilai budaya mengenai cara terbaik memperlakukan anak, secara otoriter, secara demokratis maupun realistis, akan mempengaruhi sikap orangtua dan cara mereka memperlakukan anak.

2. Faktor kepribadian adalah cara anak bereaksi terhadap orangtua dimana hal tersebut mempengaruhi sikap orangtua terhadapnya.

3. Faktor pendidikan orangtua, apabila orangtua berpendidikan tinggi umumnya akan memiliki banyak pengetahuan maupun pendidikan tentang cara mengasuh anak yang sesuai dengan kebutuhannya.

Efikasi diri adalah penilaian diri, apakah dapat melakukan tindakan yang baik atau buruk, tepat atau salah, bisa atau tidak bisa mengerjakan sesuai dengan yang dipersyaratkan. Feist mendefinisikan efikasi diri sebagai keyakinan seseorang dalam kemampuannya untuk melakukan suatu bentuk kontrol terhadap keberfungsian orang itu sendiri dan kejadian dalam lingkungan Feist (dalam Rohmatun, 2014: 3). Bandura beranggapan bahwa keyakinan atas efikasi diri seseorang adalah landasan dari agen manusia. Manusia yang yakin bahwa mereka dapat melakukan sesuatu yang mempunyai potensi untuk dapat mengubah kejadian dalam 
lingkungannya akan lebih mungkin untuk bertindak dan lebih mungkin menjadi sukses daripada manusia yang mempunyai efikasi diri yang rendah.

Efikasi diri ini terdapat pada banyak aspek dari prestasi siswa. Siswa dengan efikasi diri rendah pada pembelajaran dapat menghindari banyak tugas belajar dengan menentang. Sedangkan siswa dengan efikasi diri yang tinggi menghadapi tugas belajar tersebut dengan keinginan besar. Siswa dengan efikasi diri tinggi lebih tekun berusaha pada tugas belajar dibandingkan siswa dengan efikasi diri rendah (Santrock, 2008:216).

Menurut Bandura (dalam Ghufron, 2011:80-81) efikasi diri pada disetiap individu akan berbeda antara satu individu dengan yang lainnya berdasarkan tiga dimensi yaitu:

1. Dimensi Tingkat (Level)

Dimensi ini berkaitan dengan derajat kesulitan tugas ketika individu merasa mampu untuk melakukannya. Apabila individu dihadapkan pada tugas-tugas yang disusun menurut tingkat kesulitannya, maka efikasi diri individu mungkin akan terbatas pada tugas-tugas yang mudah, sedang, atau bahkan kemampuan yang dirasakan untuk memenuhi tuntutan perilaku yang dibutuhkan pada masing-masing tingkat. Aspek ini memiliki implikasi terhadap pemilihan tingkah laku yang dirasa mampu dilakukannya dan menghindari tingkah laku yang berada di luar batas kemampuan yang dirasakannya.

2. Dimensi Keluasan (Generality)

Dimensi ini berkaitan dengan penguasaan individu terhadap bidang atau tugas pekerjaan.Individu dapat menyatakan dirinya memiliki efikasi diri pada aktivitas yang luas, atau terbatas pada fungsi domain tertentu saja. Individu dengan efikasi diri yang tinggi akan mampu menguasai beberapa bidang sekaligus untuk menyelesaikan suatu tugas. Individu yang memiliki efikasi diri yang rendah hanya menguasai sedikit bidang yang diperlukan dalam menyelesaikan suatu tugas.

\section{Dimensi Kekuatan (strength)}

Dimensi yang ketiga ini lebih menekankan pada tingkat kekuatan atau kemantapan individu terhadap keyakinannya.

Pengharapan yang lemah mudah digoyahkan oleh pengalamanpengalaman yang tidak mendukung.Sebaliknya, pengharapan yang mantap mendorong individu tetap bertahan dalam usahanya. Meskipun kadang ditemukan pengalaman yang kurang menunjang. Dimensi ini biasanya berkaitan langsung dengan dimensi level yaitu makin tinggi taraf kesulitan tugas, makin lemah keyakinan yang dirasakan untuk menyelesaikannya (Ghufron, 2011:80-81).

\section{METODE}

Penelitian ini menggunakan pendekatan kuantitatif dengan jenis penelitian korelasional. Penelitian ini menggunakan teknik analisis korelasi dikarenakan penelitian ini bertujuan untuk mengetahui tingkat hubungan antara dua variabel, tanpa melakukan suatu perubahan apapun terhadap data yang telah diperoleh (Suharsimi Arikunto, 2010:4). Dalam penelitian ini, peneliti ingin mencari tahu ada tidaknya hubungan negatif antara pola asuh demokratis dengan efikasi diri pada siswa kelas XI IPS di SMAN 1 Ranah Batahan. Populasi dalam penelitian ini adalah siswa kelas XI IPS Di SMA N 1 Ranah Batahan dengan jumlah 119 siswa dan sampel penelitian sebanyak 92 siswa. Teknik penarikan sampel menggunakan teknik proporsional random sampling Metode pengumpulan data pada penelitian ini menggunakan skala pola asuh demokratis dan skala efikasi diri. Skala tersusun atas beberapa aitem, aitem tersebut menggunakan skala Likert. Skala menyajikan empat (4) altenatif jawaban, yaitu SL (selalu), SR (sering), JR (jarang), dan TP (tidak pernah).

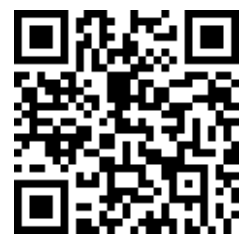

DOI PUBLIKASI https://doi.org/10.37010/int.v2i2 


\section{Firdaus}

Universitas Nahdlatul Ulama Sumatera Barat

\section{HASIL DAN PEMBAHASAN}

\section{Hasil}

\section{Uji Normalitas}

Uji normalitas data adalah syarat pokokdalam analisis data parametik seperti korelasi, karena data-data yang akan dianalisis parametik harus terdistribusi normal. Uji normalitas ini bertujuan untuk mengetahui apakah populasi terdistribusi normal atau tidak. Distribusi data yang normal menyatakan bahwa subjek penelitian tergolong representatif atau dapat mewakili populasi yang ada, sebaliknya apabila sebaran tidak normal makan dapat disimpulkan bahwa subjek tidak representatif atau tidak mewakili populasi yang ada. Uji normalitas dalam penelitian ini menggunakan uji One Sample Kolmogorov Smirnov, data dinyatakan normal jika signifikansi besar dari 0,05 (Priyatno, 2014: 69).

\begin{tabular}{|c|c|c|}
\hline Variabel & $\begin{array}{l}\text { Kolmogorov-Smirnov } \\
\mathrm{Z}\end{array}$ & Asymp sig \\
\hline Pola asuh demokratis & 1,575 & 014 \\
\hline Efikasi diri & 1,150 & 142 \\
\hline
\end{tabular}

Untuk mengetahui data terdistribusi normal atau tidak, kita dapat mengetahui dari tabel One sample kolmogorov smirnov test di atas. Kriteria pengujiannya adalah apabila signifikansi $>0,05$ maka data terdistribusi normal. Dari tabel di atas, dapat diketahui bahwa nilai kolmogorov smirnov z pola asuh demokratis adalah 1,575 dan efikasi diri adalah 1,150. Nilai signifikansi (asymptotic 2-tailed) untuk pola asuh demokratis adalah0,014 dan efikasi diri adalah 0,142. Signifikansi untuk kedua variabel lebih besar dari 0,05 maka berdistribusi normal. Jadi dapat disimpulkan bahwa pada skala pola asuh demokratis berdistribusi normal dan begitu juga pada skala efikasi diri berdistribusi normal.

\section{Uji Linearitas}

Uji linearitas merupakan uji prasyarat yang bisa dilakukan jika akan melakukan analisis korelasi dan regresi linear. Uji linearitas bertujuan untuk mengetahui apakah dua variabel penelitian secara signifikan mempunyai hubungan yang liniear atau tidak. Kedua variabel dikatakan liniear apabila memiliki taraf signifikansi kecil dari 0,05 $(\mathrm{P}<0,05)$ (Priyatno, 2014:79).

Berdasarkan pengolahan data dengan menggunakan program SPSS versi 18.0 for windows, maka diperoleh hasil uji linearitas sebagai berikut:

Tabel 2. Uji Linearitas Skala Pola Asuh Demokratis dan Skala Efikasi Diri ANOVA

\begin{tabular}{llll}
\hline & R Squared & F & Sig. \\
\hline Linearity &, 223 & 22,591 &, 000 \\
\hline
\end{tabular}

Berdasarkan tabel di atas diketahui f 22,591. Data uji linearitas di atas, dapat dilihat pada output ANOVA table, diketahui bahwa nilai signifikansi pada linearitas sebesar 0,000 maka signifikansi kecil dari $0,05(0,000<0,05)$. Maka dapat disimpulkan bahwa antara variabel pola asuh dan efikasi diri terdapat hubungan yang linear, maka asumsi linearitas terpenuhi. 
Dalam menentukan seberapa besar responden yang memiliki pola asuh demokratis dan efikasi diri yang tinggi ataupun rendah, maka diperlukan kategorisasi dalam sebaran skor yang diperoleh dari data penelitian. Sehingga akan ditemukan pula hubungan pada setiap kategori pola asuh demokratis dengan efikasi diri siswa kelas XI IPS di SMA N 1 Ranah Batahan Kabupaten Pasaman Barat.

Pola asuh demokratis memiliki skor terendah yaitu 50 dan skor tertinggi yaitu 87 dengan nilai mean sebesar 75,39. Pada efikasi diri skor terendah yaitu 49 dan skor tertinggi yaitu 100 dengan nilai mean sebesar 74,75.

Tabel 3. Sebaran Data Variabel

\begin{tabular}{lll}
\hline & Pola asuh demokratis & Efikasi diri \\
\hline Mean & 75,39 & 74,75 \\
Median & 76,00 & 72,00 \\
Minimum & 50 & 49 \\
Maksimum & 87 & 100 \\
\hline
\end{tabular}

Berdasarkan tabel di atas terdapat hasil untuk variabel pola asuh demokratis memiliki nilai mean sebesar 75,39, median sebesar 76,00, nilai minimum sebesar 50, dan nilai maksimum sebesar 87. Sedangkan untuk variabel efikasi diri memiliki nilai mean sebesar 74,75 nilai median sebesar 72,00, nilai minimum sebesar 49, serta nilai maksimum sebesar 100. Jadi data deskripsi yang didapatkan dari hasil ini yang dipergunakan untuk menentukan nilai rentang pada masingmasing kategorisasi variabel.

Tabel 4. Kategorisasi Pola Asuh Demokratis

\begin{tabular}{llll}
\hline Kategorisasi & Rentang & Jumlah & Persentase \\
\hline Rendah & $50-68$ & 13 & $14,1 \%$ \\
Tinggi & $69-87$ & 79 & $85,9 \%$ \\
Jumlah & & 92 & $100 \%$ \\
\hline
\end{tabular}

Berdasarkan tabel di atas diketahui bahwa dari 92 siswa yang diteliti, 13 siswa atau 14,1\% mwmiliki tingkat pola asuh demokratis yang rendah, 79 siswa atau 85,9\% memiliki tingkat pola asuh demokratis yang tinggi. Berdasarkan besaran persentase pola asuh demokratis siswa kelas XI IPS di SMA N 1 Ranah Batahan Kabupaten Pasaman Barat dapat dikategorikan tinggi. Kategori tinggi artinya siswa tersebut mendapatkan kasih sayang serta perhatian dari orangtua. Mereka cenderung diperbolehkan untuk memutuskan pilihan sendiri, mendapatkan arahan dari orangtua, serta mampu menerima konsekuensi dari apa yang mereka perbuat.

Tabel 5. Kategorisasi Efikasi Diri

\begin{tabular}{llll}
\hline Kategorisasi & Rentang & Jumlah & Persentase \\
\hline Rendah & $49-74$ & 54 & $58,7 \%$ \\
Tinggi & $75-100$ & 38 & $41,3 \%$ \\
Jumlah & & 92 & $100 \%$ \\
\hline
\end{tabular}

Berdasarkan tabel di atas diketahui bahwa dari 92 siswa yang diteliti, 54 siswa atau 58,7\% mwmiliki tingkat efikasi diri yang rendah, 38 siswa atau 41,3\% memiliki tingkat efikasi diri yang tinggi. Berdasarkan besaran persentase efikasi diri siswa kelas XI IPS di SMA N 1 Ranah Batahan Kabupaten Pasaman Barat dapat dikategorikan rendah. Kategori rendah artinya siswa tersebut kurang memiliki tingkat keyakinan bahwa siswa dapat menyelesaikan sesuatu, 


\section{Firdaus}

Universitas Nahdllatul Ulama Sumatera Barat

seperti saat diberikan tugas oleh guru siswa tidak dapat menyelesaikan sendiri tanpa meminta bantuan kepada teman.

\section{Uji Hipotesis}

Uji hipotesis dilakukan dengan menggunakan analisis korelasi pearson untuk mengetahui ada atau tidaknya hubungan pola asuh demokratis dengan efikasi diri. Berdasarkan hasil perhitungan dengan menggunakan program SPSS versi 18.0 for windows diperoleh hasil sebagai berikut:

\begin{tabular}{|c|c|c|}
\hline Variabel & Pearson Correlation & Sig \\
\hline $\begin{array}{l}\text { Pola Asuh Demokratis } \\
\text { Efikasi Diri }\end{array}$ & 0,472 & 0,000 \\
\hline
\end{tabular}

Hasil analisis pada tabel di atas menunjukkan bahwa nilai koefisien pearson correlation pola asuh demokratis dan efikasi diri pada siswa kelas XI IPS di SMA N 1 Ranah Batahan Kabupaten Pasaman Barat sebesar 0,472 dan nilai koefisien sig sebesar 0,000. Jika nilai signifikansi kecil dari 0,05 berarti hipotesis diterima, jika nilai besar dari 0,05 maka hipotesis ditolak.

Nilai signifikansi pola asuh demokratis dan efikasi diri pada siswa kelas XI IPS di SMA N 1 Ranah Batahan Kabupaten Pasaman Barat adalah 0,001 $(0,001<0,05)$ yang berarti taraf signifikansi antara dua variabel menunjukkan adanya hubungan antara pola asuh demokratis dengan efikasi diri pada siswa kelas XI IPS di SMA N 1 Ranah Batahan Kabupaten Pasaman Barat.

Hasil penelitian menunjukkan bahwa dari 92 siswa yang diteliti, 79 siswa atau 85,9\% memiliki tingkat pola asuh demokratis yang tinggi. Pola asuh demokratis yang tinggi artinya siswa mendapatkan kasih sayang dan perhatian dari orangtua, mendapatkan hak untuk menentukan keputusan sendiri dan menanggung resiko dari apa yang telah diperbuat. Sedangkan sebanyak 54 siswa atau 58,7\% memiliki tingkat efikasi diri yang rendah. Apabila siswa tidak memiliki efikasi diri yang tinggi maka siswa akan lebih memilih diam saja ketika diminta untuk memberikan pendapat, malu ketika disuruh maju kedepan tidak percaya diri dengan kemampuan yang dimiliki. Sedangkan apabila siswa memiliki efikasi diri yang tinggi maka siswa akan percaya dengan kemampuan dirinya, mampu menyelesaikan masalah yang dihadapi serta tidak diam saja ketika menghadapi kesulitan ketika mengerjakan tugas yang diberikan guru.

Berdasarkan penelitian yang dilakukan, didapatkan nilai signifikansi pola asuh demokratis dan efikasi diri pada siswa kelas XI IPS di SMA N 1 Ranah Batahan Kabupaten Pasaman Barat adalah $0,001(0,001<0,05)$ yang berarti taraf signifikansi antara dua variabel menunjukkan adanya hubungan antara pola asuh demokratis dengan efikasi diri pada siswa kelas XI IPS di SMA N 1 Ranah Batahan Kabupaten Pasaman Barat. Kemudian nilai koefisien pearson correlation yang didapatkan adalah sebesar 0,472 . Sedangkan nilai $\mathrm{R}$ square menunjukkan angka 0,223 yang berarti sumbangsih pola asuh demokratis terhadap efikasi diri sebesar 22,3\%.

Penelitian yang dilakukan oleh Musyafa (2017) Fakultas Psikologi Maulana Malik Ibrahim Malang, Hubungan Efikasi Diri dengan kecemasan Komunikasi dalam bersiaran pada penyiar radio Kota Malang, berdasarkan hasil analisa ditemukan bahwa terdapat hubungan negative antara efikasi diri dengan kecemasan komunikasi dengan nilai $r=-0,766$, sig $(0,01)$. Artinya semakin tinggi efikasi diri penyiar maka semakin rendah kecemasannya dalam melakukan siaran radio, dan sebaliknya semakin rendah efikasi diri penyiar maka akan semakin tinggi tingkat kecemasan penyiar dalam melakukan siaran. 
Penelitian yang dilakukan oleh Alvita Anjarsari Hamungpuni (2017) tentang Hubungan Pola Asuh Demokratis Orangtua Dengan Kemampuan Mengelola Emosi Siswa/i Kelas XI IPA 2 dan XI IPS 2 Di SMA BOPKRI 2 Yogyakarta Tahun Ajaran 2016/2017. Penelitian ini menunjukkan bahwa terdapat hubungan yang positif dan signifikan antara pola asuh demokratis orangtua dengan kemampuan mengelola emosi. Artinya terdapat hubungan positif antara variabel pola asuh demokratis dan kemampuan mengelola emosi siswa.

Penelitian yang dilakukan oleh Chelsea Sulastry Sianipar, Dian Ratna Sawitri (2015) berdasarkan hasil analisa sumbangan efektif dari pola asuh otoritatif orangtua terhadap efikasi diri dalam mengambil keputusan karir sebesar $16 \%$ sedangkan sisanya $84 \%$ dipengaruhi faktor lain.

Penelitian yang dilakukan oleh Rohmatun (2014) berdasarkan hasil analisa sumbangan efektif dari pola asuh otoriter terhadap efikasi diri sebesar $11,6 \%, 88,4 \%$ sisanya dipengaruhi oleh faktor lain.

Penjelasan hasil analisis dan pembahasan di atas menunjukkan bahwa penelitian ini pada intinya sudah mampu untuk membuktikan hasil hipotesis yang menyatakan adanya hubungan pola asuh demokratis dengan efikasi diri yang cukup signifikan pada siswa kelas XI IPS di SMA N 1 Ranah Batahan Kabupaten Pasaman Barat.

\section{PENUTUP}

Berdasarkan hasil penelitian dalam pembahasan, maka dapat dikatakan bahwa terdapat hubungan antara pola asuh demokratis dengan efikasi diri pada siswa kelas XI IPS di SMA N 1 Ranah Batahan Kabupaten Pasaman Barat. Secara garis besar peneliti menarik kesimpulan penelitian ini sebagai berikut:

1. Kategori pola asuh demokratis pada siswa kelas XI IPS di SMA N 1 Ranah Batahan Kabupaten Pasaman Barat dikategorikan tinggi, karena dari jumlah subjek 92 siswa, 79 siswa dinyatakan memiliki kategori pola asuh demokratis yang tinggi.

2. Kategori efikasi diri pada siswa kelas XI IPS di SMA N 1 Ranah Batahan Kabupaten Pasaman Barat dikategorikan rendah, karena dari jumlah subjek sebanyakn 92 siswa, 54 siswa dinyatakan memiliki efikasi diri kategori rendah.

3. Terdapat hubungan antara pola asuh demokratis dengan efikasi diri pada siswa kelas XI IPS di SMA N 1 Ranah Batahan Kabupaten Pasaman Barat.

\section{DAFTAR PUSTAKA}

Ali, M. \& Ansori. (2011). Psikologi Remaja-Perkembangan Peserta Didik Edisi 7. Jakarta: PT Bumi Aksara

Alvita, A. H. (2017). Hubungan Pola Asuh Demokratis Orangtua Dengan Kemampuan Mengelola Emosi Siswa/siswi Kelas XI IPA 2 dan XI IPS 2 Di SMA BOPKRI 2 Yogyakarta Tahun Ajaran 2016/2017. Skripsi tidak diterbitkan. Universitas Sanata Dharma

Bahri, S., Djamarah. (2014). Pola Asuh Orangtua Dan Komunikasi Dalam Keluarga : Upaya Membangun Citra Membentuk Pribadi Anak. Jakarta: PT Rineka Cipta

Chelsea, S.S. (2015). Pola Asuh Otorotatif Dan Efikasi Diri Dalam Mengambil Keputusan Karir Pada Mahasiswa Tahun Pertama. Jurnal Empati. Vol. 4 No. 4

Djukanda, H. (2008). "Pengembangan Konsep Diri yang Positif Pada SD Sebagai Dampak Penerapan Umpan Balik (feedback) Dalam Proses Pembelajaran Penjas. Jurnal Pendidikan Dasar. Vol. IX”.

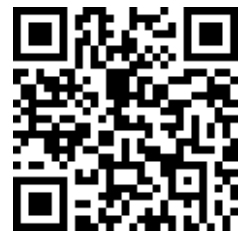

DOI PUBLIKASI https://doi.org/10.37010/int.v2i2 


\section{Firdaus}

Fuadi, A. (2012). Hubungan Persepsi Pola asuh Demokratis Orangtua Dengan Komunikasi Personal Antara Remaja Dan Orangtua. Naskah Publikasi.

Universitas Muhammadiyah Surakarta

Ghufron, Nur \& Risnawita, Rini. (2011). Teori-Teori Psikologi. Yogyakarta: RRuzz Media

Hurlock, E. B (2002). Psikologi Perkembangan 5th Edition. Jakarta: Erlangga

Lestari, E. (2013). Hubungan Antara Pola asuh Orangtua Dengan Prestasi Belajar Siswa Konsentrasi Patiseri SMK Negeri 1 Sewon Bantul. Skripsi. Universitas Negeri Yogyakarta

Lestari, S. (2012). Psikologi Keluarga. Penanaman Nilai Dan Penanganan Konflik

Dalam Keluarga. Jakarta: Kencana Prenda Media Grup

Mutiah, diana. (2010). Psikologi Bermain Anak Usia Dini. Jakarta: Prenada Media

Rita, E. I dkk. (2008). Perkembangan Peserta Didik. Yogyakarta: Penerbit UNY Press.

Rohmatun. (2014). Hubungan Antara Pola Asuh Otoriter Dengan Self Efficacy

Pada Mahasiswa yang Sedang Menyelesaikan Skripsi Di Universitas Islam Sultan Agung Semarang. Jurnal. Vol. 9 No. 2

Santrock. (2008). Psikologi Pendidikan Educational Psychology, Jakarta: Salembang Humanika. Sardiman. (2001). Interaksi dan Motivasi Belajar Mengajar. Jakarta: Rineka Cipta 